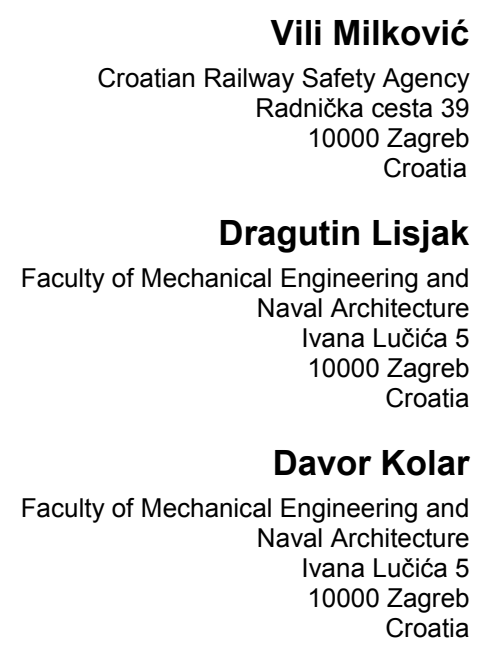

Vili Milković

Safety Agency

roatia

Engineering and vana Lučića 5

angineering and vana Lučića 5 Croatia

\section{New Reliability-Based Model of Stock Optimisation for Railroad Passenger Wagon Maintenance}

Today's railroad passenger wagons experience a large frequency of failures due to a large number of usage hours, and consequently planning maintenance is complex and expensive. Due to high maintenance costs, special attention should be given to the planning of part storage. This study develops a model which by using the data collected in the maintenance process, serves in optimising the costs of stock parts for a set level of reliability. The data on drive schedules and wagon repairs, mean time between failures and maintenance costs were collected over a year by a rail carrier for its entire rolling stock of passenger wagons. The first phase of developing the model using regression methods provided mathematical models of reliability dependency in terms of train use time and costs of spare parts for groups of passenger wagons grouped into technical characteristics. In the second phase, the problem of optimal stocks was solved by applying linear programming methods. The newly obtained model can be applied in practice as a tool for optimising the required stocks of parts based on a set level of equipment reliability and set maintenance costs.

Keywords: optimising stock, equipment reliability, maintenance, passenger carriages

\section{INTRODUCTION}

Railway systems are a key initiator of economic development, and railway cars have a primary role to that effect, and due to the intense use and usability of railway cars as well as frequency of faulty components and devices, maintaining them is essential. Maintenance is a series of activities undertaken to keep the system in proper working order or return it to a state in which set functions can be executed. Furthermore, maintenance is a series of essential activities in which equipment, machinery, facilities or production function in a set manner, developing work-related features within stipulated limits along with required effectiveness, without delays, in a quality manner, while adhering to the protection of the environment and people, and also suitable logistics [1]. The most commonly accepted definition of maintenance is an action necessary for the normal functioning or establishing once more the entirety and functioning of a technical system (TS), which includes inspection, overhauls, repairs, preservation and replacement of parts [2]. Today, existing maintenance strategies are divided into corrective maintenance (CM), preventive maintenance (PM), terotechnology, logistic maintenance, condition-based maintenance (CBM), planned maintenance, total productive maintenance (TPM), reliability-centered maintenance (RCM), and selfmaintenance [3-5]. Regular maintenance is essential for

Received: June 2020, Accepted: August 2020

Correspondence to: Vili Milković

Croatian Railway Safety Agency,

Radnička cesta 39, 11000 Zagreb, Croatia

E-mail: vilim351@gmail.com

doi;10.5937/fme2004914M

(C) Faculty of Mechanical Engineering, Belgrade. All rights reserved preserving railroad cars and their integral components in an operational state with the aim of eliminating failures. Omitted and inadequate maintenance activities may lead to trains not arriving on time, the termination of train schedules, dangerous situations and even serious accidents, where all of the mentioned adverse events primarily affect transport safety, including competitiveness and profitability of the rail carrier, and are exceptionally important. Maintenance processes are becoming increasingly complex for a number of reasons. Sophisticated passenger wagons and locomotives have replaced mechanical systems with systems that combine mechanical, electronic and computer devices by incorporating completely different characteristics in terms of degradation and faults. This leads to more complex requirements in planning maintenance as well as professional and scientific approaches to planning optimal quantities of spare parts and materials. An evaluation of maintenance strategy requires modelling the effects of possible alternative strategies in terms of system performance, as well as costs during the lifecycle. However, the increased system complexity including increased requirements for system performance in terms of reliability and safety results inevitably in complexities when evaluating maintenance strategies. In addition to the concept of maintenance, it is also linked to the concept of system reliability. The consequences of not considering reliability are huge material losses and the slowing down of technological progress in many vital areas. Moreover, reliability is an interesting, prospective and appreciative scientific discipline, the concept and ideas may find their way into all branches of engineering. Knowledge and engineering in the area of reliability provides a wide scope of 
methods which when applied lead to the optimal consumption of materials, time and money while achieving greater efficiency. Mean time between failures (MTBF) is one of the most important system reliability parameters indicating the average time between system failures and is used for repairable devices and systems. If viewed as only one device, it is then mean time between failures [6]:

$$
M T B F=\frac{1}{k} \sum_{i=1}^{k} t_{i} .
$$

where: $t_{i}$ - operating time between $(i-1)$ and the $i$-th failure, $k$ - total number of failures in the observed time period.

If $n$ elements are observed, then the mean time between failures is:

$$
M T B F=\frac{\sum_{J=1}^{n} \sum_{i=1}^{k_{j}} t_{i j}}{\sum_{j=1}^{n} k_{j}} .
$$

where: $t_{i}$ - operating time between $(i-1)$ and the i-th failure, $k$ - total number of failures in the observed time period.

Increasing the mean time between failures results in reliability increasing. The reliability function $R(t)$ is the level of system operation in time.

$$
R(t)=e^{-\lambda t} .
$$

where: $R(t)$ - system reliability, $\lambda$-failure rate (1/MTBF), $\mathrm{t}$ - time (in minutes, hours, days..).

The reliability of parallel connected elements is calculated as [6]:

$$
R_{p}=1-\left[\left(1-R_{1}\right)\left(1-R_{2}\right) \ldots . .\left(1-R_{n}\right)\right] .
$$

where: $R_{l}, R_{2} \ldots R_{n}$ - reliability of particular system components.

\subsection{Literature survey}

Existing methods and techniques in predicting maintenance and reliability can be classified into a number of groups, where the most common methods applied in research are statistical and data mining methods. Based on the analysis of data on railroad cars (passenger wagons), Milković et al. [7] applied data mining methods (cluster and Pareto analysis, multi-dimensional scaling) with the aim of determining the frequency of faults in devices and equipment on air-conditioned passenger wagons operated by rail carriers in the Republic of Croatia. Applying the mentioned methods identifies devices with the greatest frequency of faults, and using mathematical models can determine certain parameters of mean time between failures and repair time. Based on the obtained results, the proposal is to install devices with greater reliability, i.e., a greater mean time between failures and reduced repair time, which has the effect of reducing wagon maintenance costs and increasing fleet reliability for a certain series of passenger wagons. The research undertaken by Conradie et al. [8] led to proposals for quantifying the reliability of railway cars in the Republic of South Africa by using fault statistics. A distribution of faults and interdependency of various systems were used to determine the effect of faulty components on the reliability of the entire system and determine the reliability of particular railroad cars and trains. Decision tree methods and Monte Carlo simulations were applied by Szkoda et al. [9] in estimating reliability and availability of diesel locomotives, type $6 \mathrm{Dg}$, in Polish Railways. The primary goal of these methods was to determine the reliability indicator and identify the 'weakest' components in railroad cars which had the greatest effect on reducing the technical availability of railroad cars. The estimation of availability and reliability was conducted on a sample of 75 diesel locomotives. Furthermore, Milutinović et al. [10] presented the possibility of determining the effect of reliability of railroad cars and their availability using an example that takes into consideration the real values of such characteristics for conditions in Serbian Railways. With the application of abbreviated Petri nets and in combination with the Monte Carlo simulation, Eisenberger et al. [11] conducted research for a railroad fleet in order to estimate maintenance. In the first step, the application of the abbreviated Petri nets was illustrated on a theoretical case study which contains a conditionbased system maintenance. In the second case study, by covering a number of real case studies, the use of three components in railroad cars was modelled and compared with processes and actual data from relevant fields. There are also ways in which an optimal policy in preventive maintenance for light rail systems is determined in terms of reliability, availability and maintenance costs. The maintenance policy defines one of three already defined actions for preventive maintenance in certain time intervals for each of the brake subsystems. Based on data for operation, maintenance and faults, Corman et al. [12] modelled system and subsystem reliability with respect to maintenance policies using Weibull distribution. Nikšić's [13] doctoral thesis explored availability, reliability and the structure of a railroad car fleet belonging to Croatian Railways and also analysed faults in a particular series of tow railroad cars and maintenance costs. Based on the research results, an optimal model strategy for the use and maintenance of the railroad tow car fleet was devised. The model is divided into three areas (railroad cars, maintenance and facility technologies). Costs associated with the optimal maintenance strategy were compared with existing costs in maintaining railroad cars. The results indicated the justifiability of ongoing development and application of models as it allows significant savings for railroad car owners and rail carriers with significant increases in reliability and availability of railroad car fleet. In the previously cited research from a number of years ago, research relating to the maintenance and reliability of railroad cars was shown.

\section{METHODOLOGY}

The aim of the research is to develop a model for optimising part stocks for a given level of part reliability within the railroad wagon maintenance process. In the first phase, mathematical regression models of dependency for railroad car reliability in terms of operating times and costs of replacement parts for groups of pas- 
senger wagons were derived based on data mining, i.e., maintenance parameters and grouped in line with technical characteristics. The second phase devised a model for determining the optimal quantity of spare parts using a linear programming method. A workflow diagram for resolving relevant issues is shown in Figure 1.

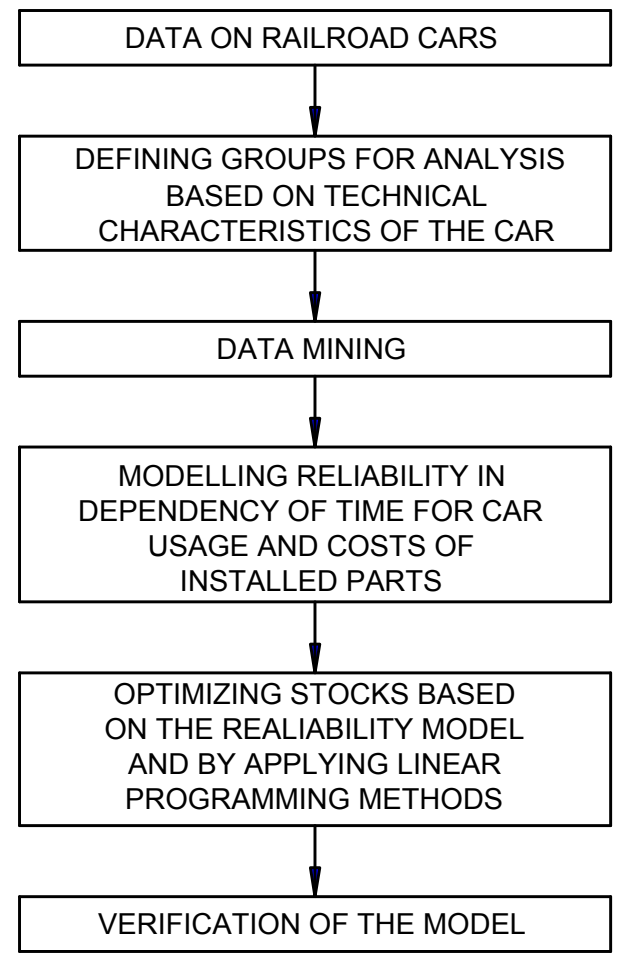

Figure 1. Workflow for resolving issues

\subsection{Regression analysis}

Regression analysis is a statistical method with the goal being to model relationships between dependent (also called variables or regresands) and one or more independent variables (often called explanatory variables or regressors). They are most commonly used when relationships need to be described quantitatively or the values of dependent variables have to be forecasted. The most common regression analysis model is the linear regression, where the graph line (or more complex linear function) which best complies with the data based on certain mathematical criteria is used. For example, the usual least squares model calculates the graph line, sums the squares of deviation between the actual data and this graph line, thereby minimising the remaining (residual) sum of squares [14]. Regression analysis is most used for two conceptually different purposes. Firstly, regression analysis is often used for estimating and predicting where the application overlaps with the machine learning. Secondly, in some situations, regression analysis can be used for concluding the causeeffect relationship between independent and dependent variables. Regression between the two variables $\mathrm{x}$ and $\mathrm{y}$ can be shown using the following expression:

$$
y_{i}=f\left(x_{i}\right)+e_{i}(i=1, \ldots \ldots, n) .
$$

where: $y_{i}$ - is the dependent variable, $f\left(x_{i}\right)$ - is the regression function, and $e_{1}, \ldots, e_{n}-$ are the independent random variables.

When there is only one independent variable, it refers to a one-dimensional or simple regression model, but when there is more than one independent variable it then refers to a multiple regression model. Furthermore, the coefficient of determination $r^{2}$ provides information on the strength of the functional relationship between variables $x$ and $y$. The closer the coefficient value of $r^{2}$ is to 1 , dependency is stronger and vice versa. The coefficient of determination $r$ is given in the following manner:

$$
r^{2}=\frac{\sum_{i=1}^{n}\left(\hat{y_{i}-\bar{y}}\right)^{2}}{\sum_{i=1}^{n}\left(y_{i}-\bar{y}\right)^{2}}
$$

The values of the determination coefficient vary in the internal $0 \leq r^{2} \leq 1$. The regression model is most typical when this indicator is closer to 1 . In practice, sometimes it is difficult to find the variable which properly describes the dependency phenomenon, hence this boundary of representativeness is lowered to 0.6 [15].

\subsection{Optimisation using linear programming}

Linear programming solves system optimisation problems within set limits. Some of the definitions are that linear programming is an operations research technique, where optimisation quantitative models are linear: limitations and the goal, i.e., the goal function are linear functions [16]. Furthermore, linear programming can be defined as operations research which by definition performs "mathematical modelling of real processes for the purpose of making optimal decisions." Based on available data, operations research enables managers to make effective decisions and develop more productive systems. The linear programming model is used to resolve numerous technical-technological as well as techno-economic issues when an optimal solution is sought, e.g., maximum productivity, maximum profit, optimal use of materials and minimum production costs [17]. The basic features of linear programming are:

1. Linearity of relationship between variables - methods and procedures can resolve such problems where the goal function is expressed by using a linear combination of variables, where a group of constraints is given using a system of linear equations and inequalities.

2. Ability to define the goal - an important feature of this approach is to clearly define the goal and optimisation criteria in resolving the linear programming problem, and then mathematically define it.

3. Multiple possible solutions - there is no sense in using linear programming models if each problem has only one solution.

4. Constraints - constraints in the form of limiting factors such as material and time are placed on variables appearing in models. The problem of the standard maximum is a special type of linear programming which is simple to analyse. It is a form of linear programming for maximising the goal function as shown in equation (7) [18]:

$$
Z=c_{1} x_{1}+c_{2} x_{2}+\ldots \ldots \ldots+c_{n} x_{n} .
$$


where:

$c_{1}, c_{2}, \ldots \ldots c_{n}-$ coefficients of proportionality with variables in the goal function

$x_{1}, x_{2} \ldots x_{n}$ - variables (optimal quantities of spare parts) providing extreme values of the goal function (minimum or maximum).

In addition to inequalities (functions) of constraints:

$$
\begin{aligned}
& c_{1} x_{1}+c_{2} x_{2}+\ldots \ldots \ldots+c_{n} x_{n} \leq b_{1} \\
& c_{1} x_{2}+c_{2} x_{2}+\ldots \ldots \ldots+c_{n} x_{n} \leq b_{2} \\
& c_{1} x_{2}+c_{2} x_{2}+\ldots \ldots \ldots+c_{n} x_{n} \leq b_{n} .
\end{aligned}
$$

where:

$c_{1}, c_{2}, \ldots . . c_{n}-$ coefficients of proportionality in addition to variables in constraints, (unit price for each spare part),

$b_{1}, b_{2}, \ldots \ldots b_{n}-$ constraint elements.

\subsection{Algorithm of model for stock optimisation based on reliability}

The Matlab application was used to devise the algorithm for calculating optimal stocks of spare parts and materials as well as optimal maintenance costs, based on the given input parameters of unit prices for parts and materials $\left(\mathrm{c}_{1}\right.$ to $\left.\mathrm{c}_{567}\right)$ and limited quantities of spare parts obtained for the observed period $\left(\mathrm{x}_{1}\right.$ to $\left.\mathrm{x}_{567}\right)$ of study. The next step involved setting the goal function $(Z)$ and system of 36 inequalities with limits $\left(b_{1}\right.$ to $\left.b_{36}\right)$ for the values of material costs $\left(\mathrm{T}_{\mathrm{m}}\right)$ for the desired and given reliability (values from graphs in Figures 4 and 6). Furthermore, the procedure is defined for invoking the optimisation algorithm after which the calculated resulting optimal quantities of spare parts are provided (Table 2) and the goal function (Z). Finally, the algorithm (Figure 2) is verified and tested.

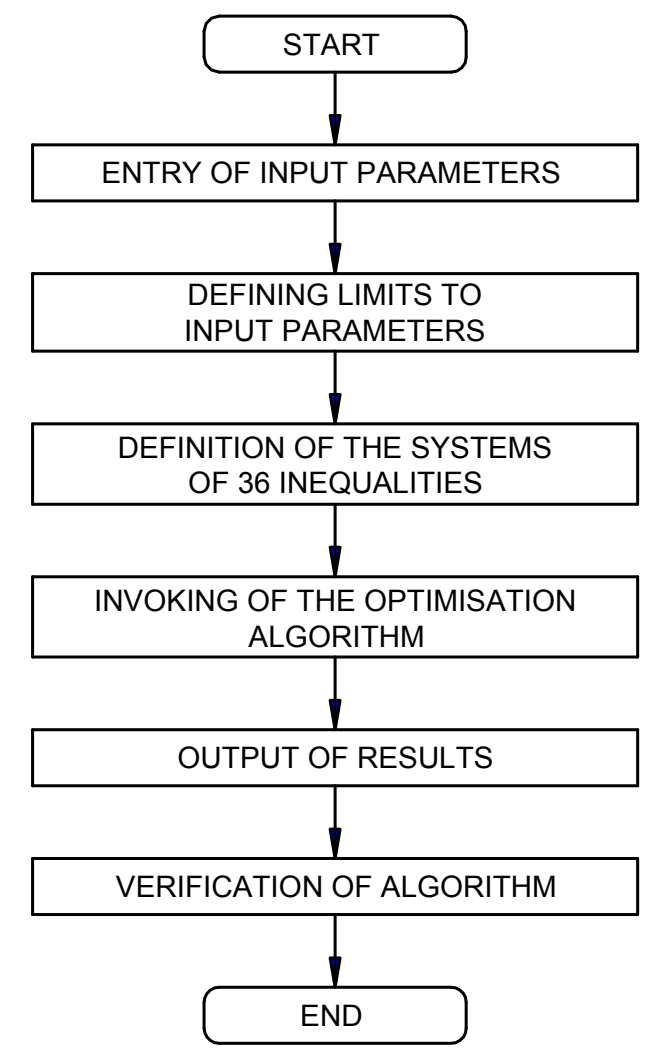

Figure 2. Steps in devising model algorithm

\section{RESULTS AND DISCUSSION}

This study uses collected data on prices and quantities of consumed spare parts and materials, as well as operating time in exploiting and repairing an entire fleet of rail carrier passenger wagons in a single year. All in all, 36 groups were created based on technical constructive characteristics (Table 1), where the research included consumption for a total of $N=567\left(\mathrm{x}_{1}\right.$ to $\left.\mathrm{x}_{567}\right)$ positions in a single year of spare parts and materials along with unit $\left(\mathrm{c}_{1}\right.$ to $\left.\mathrm{c}_{567}\right)$ and total prices installed into all series of passenger wagons. In the first phase of the research, regression modelling provided mathematic models of dependency for railroad car reliability based on operating time: $R(t)-t$ (reliability - operating time) and $R(t)-T_{m}$ (reliability - costs of parts and materials) for each previously defined group, where the mean time between failures was calculated in line with equation (2) for each group (Table 1). The obtained models indicate that the costs of the installed parts and materials can be calculated for each value of reliability for a group of railroad cars at any given time. In the second phase of the research, a total of 36 inequalities were defined for the mentioned groups of railroad cars and the goal function was calculated for the costs of replacing the parts. Based on the given equations (7) and (8), the optimal quantity of spare parts and materials for the desired reliability of railroad car group was calculated. The reliability of elements (elements are railroad cars in this research) and devices decreases during the time spent in operation, i.e., exploitation. The results in Table 1 indicate that railroad cars with a smaller mean time between failures are those that have incorporated modern devices for power supply - static frequency converters (Groups 2, 3, 4, 5 and 6)., air conditioning units (Groups 13, 14 and 15), automatic closing doors (Group 22) and sanitary vacuum systems (Group 21). Compared to the results obtained for the above-mentioned groups, groups with classic power sources (Group 1) and heating systems (Group 12), doors without automatic closing (Group 23) and classical sanitary systems (Group 20) had a greater mean time between failures.

The research results show that there is greater reliability, i.e., a greater mean time between failures for those groups which only comprise mechanical components (Groups 1, 12, 20 and 23) and are older compared to the groups which comprise mechanical and electronic components (Groups 2, 3, 4, 5, 6, 13, 14, 15 and 21) from newer production. The obtained results can be explained by a greater frequency of defects due to actual and temporary faults on the associated software and electronic modules.

The brake systems (Groups 7, 9 and 11) are from older production and have a smaller mean time between failures compared to sophisticated brake systems (Groups 8 and 10) of newer production, which can simply be explained with a greater reduction in reliability of older equipment with respect to newer equipment. Regarding brake systems, the reduction in reliability of devices from an older production can be explained due to the lack of original spare parts produced using an original licence and the absence of original equipment manufacturers, where the alternative is to install parts of secondary quality. 
Table 1. Results of mean time between failures for groups of classic passenger cars

\begin{tabular}{|c|l|l|l|l|c|}
\hline Group & \multicolumn{1}{|c|}{ Name } & MTBF $[\mathrm{h}]$ & Group & \multicolumn{1}{|c|}{ Name } & MTBF $[\mathrm{h}]$ \\
\hline 1. & Classic power sources & 163.05 & 19. & Type D bogie & 181.92 \\
\hline 2. & Type A static converters & 146.86 & 20. & Classic sanitary system & 163.92 \\
\hline 3. & Type B static converters & 172.23 & 21. & Vacuum sanitary system & 161.76 \\
\hline 4. & Type C static converters & 147.28 & 22. & Automatic closing doors & 156.60 \\
\hline 5. & Type D static converters & 198.80 & 23. & Doors without automatic closing & 172.17 \\
\hline 6. & Type E static converters & 124.72 & 24. & Mass of wagon between 40 and 45 tons & 154.96 \\
\hline 7. & Type A brake system & 144.18 & 25. & Mass of wagon between 45 and 50 tons & 157.70 \\
\hline 8. & Type B brake system & 172.72 & 26. & Age of wagon over 50 years & 145.67 \\
\hline 9. & Type C brake system & 137.47 & 27. & Age of wagon between 40 and 50 years & 140.50 \\
\hline 10. & Type D brake system & 174.73 & 28. & Age of wagon between 30 and 40 years & 171.66 \\
\hline 11. & Type E brake system & 149.71 & 29. & Age of wagon less than 30 years & 151.32 \\
\hline 12. & Classic heating system & 169.04 & 30. & Wagon speed up to 120 km/h & 149.51 \\
\hline 13. & Type A air conditioning device & 158.69 & 31. & Wagon speed up to 160 km/h & 164.53 \\
\hline 14. & Type B air conditioning device & 152.77 & 32. & Wagon speed up to 200 km/h & 151.32 \\
\hline 15. & Type C air conditioning device & 149.66 & 33. & Servicer of A passenger wagons & 161.86 \\
\hline 16. & Type A bogie & 144.18 & 34. & Servicer of B passenger wagons & 162.25 \\
\hline 17. & Type B bogie & 149.71 & 35. & Wagons for domestic transport & 154.96 \\
\hline 18. & Type C bogie & 143.53 & 36. & Wagons for international transport RIC & 164.09 \\
\hline
\end{tabular}

Given the other technical characteristics, wagons manufactured more than 50 years ago (Group 26) and those between 40 and 50 (Group 27) have a smaller mean time between failures, i.e., reliability of wagons manufactured between 30 and 40 years ago (Group 28) and within the last 30 years (Group 29), which is as expected in terms of age. The results relating to the servicer (Groups 33 and 34) show approximately the same mean time between failures, which is an indication that there is no difference in the manner of servicing by both companies.

Passenger wagons with speeds of up to $120 \mathrm{~km} / \mathrm{h}$ (Group 30) have a smaller mean time between failures with respect to those with speeds of up to $160 \mathrm{~km} / \mathrm{h}$ and $200 \mathrm{~km} / \mathrm{h}$ (Groups 31 and 32), which can be explained by the fact that the wagons are of older production models.

Finally, passenger wagons intended for transport abroad (Group 36) showed greater mean time between failures with respect to wagons used for domestic transport (Group 35), which can be explained by the fact that more attention to maintenance cycles is given to wagons intended for transport abroad. Based on the obtained results, given below are separate and presented derived mathematical models of reliability for two groups (from a total of 36) of the oldest passenger wagons equipped with rotational classic power sources (Group 1) and modernised passenger wagons (newer production models) equipped with air conditioning systems from manufacturer A (Group 13).

The reliability (calculed with equations (3) and (4) for each group) dependency of the wagons in terms of operating time for Group 1 (Figure 3) and Group 13 (Figure 5), as well as the reliability dependency of wagons in terms of spare part costs and materials for Group 1 (Figure 4) and Group 13 (Figure 6). Based on the derived models, the total cost of parts and materials for each group of railroad cars as well as their reliability and vice versa can be obtained at any time during their exploitation.

The estimated mathematical model for calculating reliability as dependency in terms of time spent in operation shown in Figure 3 is:

$$
R_{1}(t)=3.54-0.469 \cdot \ln (t) .
$$

where: $R_{I}(t)$ - reliability of Group 1 of cars, $t-$ operating time of Group 1 of cars (hours).

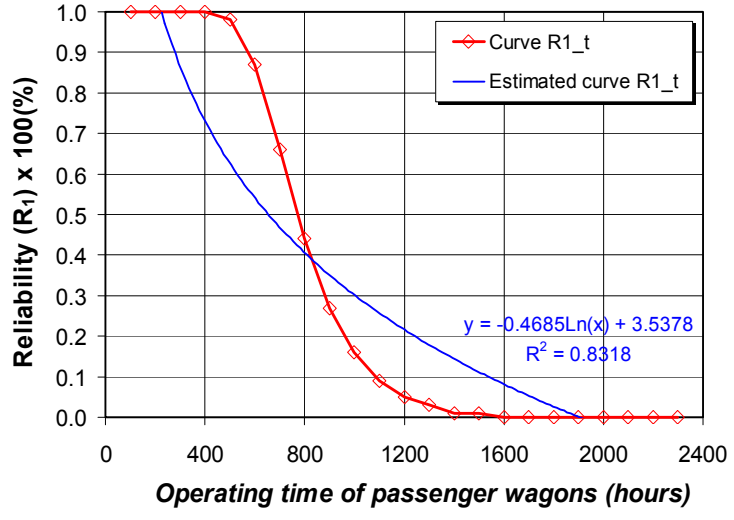

Figure 3. Reliability - operating time curve for passenger wagons in Group 1

The obtained model in the first 400 hours of the passenger wagons in exploitation shows for Group $1 \mathrm{a}$ car reliability of $100 \%$ whereas in the interval from 401 to 1,300 hours of operation, the reliability decreases and behaves linearly based on the curve $R_{1, \text { lin }}(t)=1.34$ $0.001 \cdot t$ along with a coefficient of determination 0.8691 . From 1,301 hours and onwards, the reliability of Group 1 cars decreases to zero. The coefficient of determination for dependency of passenger car reliability in terms of time, based on equation (9) in exploitation is very high during and amounts to 0.832 , which describes a strong link between the two values. Given below is the reliability dependency curve (Figure 4) for Group 1 passenger wagons in terms of total costs of parts and materials for repairs, i.e., maintenance.

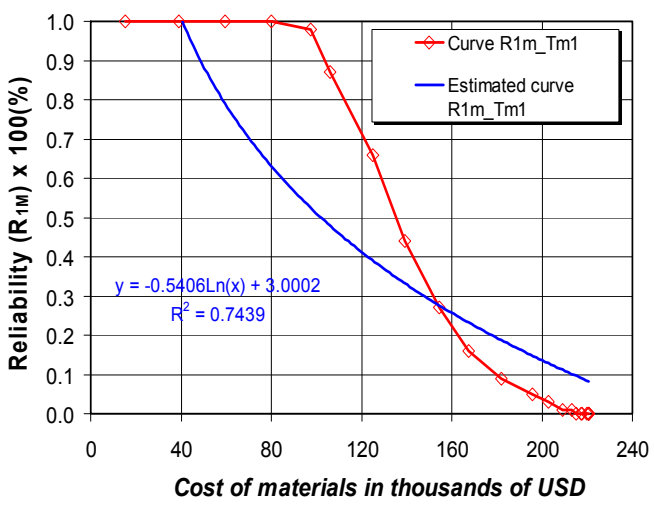

Figure 4. Curve for reliability-costs of materials Group 1 passenger wagons 
The estimated mathematical model for calculating reliability as a dependency of material costs in Figure 4 is as follows:

$$
R_{1 m}(t)=3.02-0.541 \cdot \ln \left(T_{m 1}\right) .
$$

where: $R_{l m}(t)$ - reliability of Group 1 cars, $T_{m l}$ - total cost of Group 1 materials (US Dollars).

The curve model in Figure 4 for Group 1 passenger wagons, shows an increase in costs of parts and materials up to 80,000 US Dollars, reflecting a $100 \%$ railroad car reliability. The increase in costs of materials continues to increase up to 225,000 US Dollars until the moment when reliability for Group 1 cars falls to zero. The coefficient of determination for dependency of passenger wagon reliability in terms of part costs and materials is 0.7439 based on equation (10). For example, maintaining railroad car reliability at $90 \%$ requires allocating approx. 105,250 US Dollars according to the graph in Figure 4.

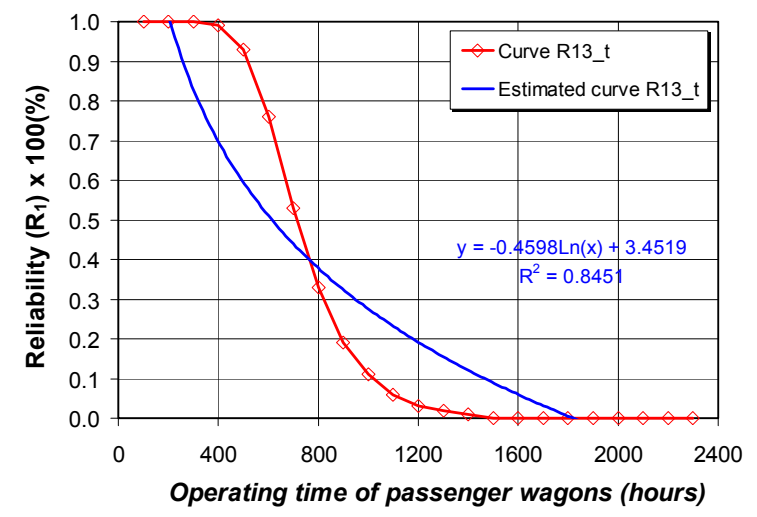

Figure 5. Reliability - operating time curve for passenger wagons in Group 13

The estimated mathematical model for calculating reliability as dependency in terms of time spent in operation shown in Figure 5 is:

$$
R_{13}(t)=3.452-0.46 \cdot \log (t) \text {. }
$$

where: $R_{13}(t)$ - reliability for Group 13 cars, $t-$ operating time for Group 13 cars (hours).

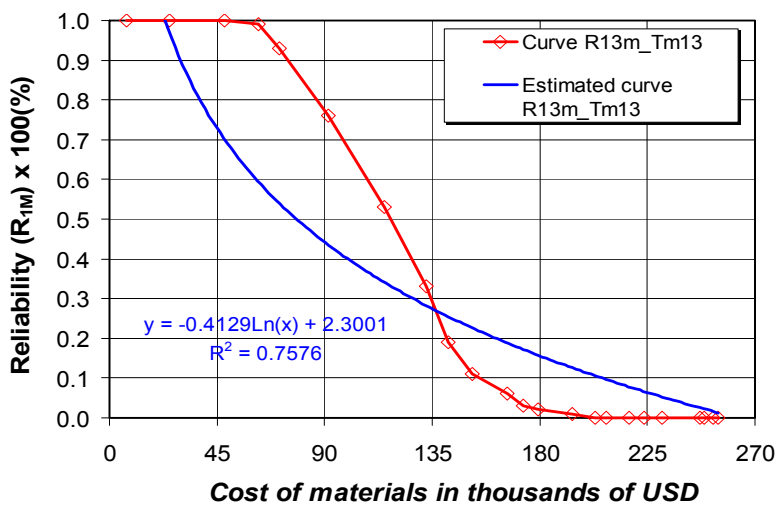

Figure 6. Curve for reliability-costs of materialsGroup 13 passenger wagons

The derived model in the first 300 hours for the group of passenger wagons in use shows car reliability at $100 \%$ for Group 13, whereas in an interval of 301 to 1,500 hours, the reliability decreases and acts linearly based on the curve $R_{13, \text { lin }}(t)=1,2514-0,001 \cdot t$ with a coefficient of determination of 0.863 . From 1,501 hours onwards, reliability decreases to zero for Group 13 cars. The coefficient of determination for reliability dependency regarding passenger vehicles in terms of time in use according to formula (11) is very high and amounts to 0.895 , which also reveals a strong link between the two values.

The derived mathematical model describing the curve in Figure 6 is as follows:

$$
R_{13 m}(t)=2.3-0.413 \cdot \log \left(T_{m 13}\right) .
$$

where: $R_{13 m}(t)$ - reliability of Group 13 cars, $T_{m 13}-$ total cost of Group 13 materials (US Dollars).

The curve in Figure 6 for Group 13 passenger wagons shows an increase in costs of parts and materials amounting up to 62,456 US Dollars and reflecting a car reliability of $100 \%$. The increase in costs of materials increases to 202,500 US Dollars up until the reliability falls to zero for Group 13 cars. The coefficient of determination of dependency for passenger wagon reliability in terms of costs of materials and in line with equation (12) amounts to 0.7439 . Hence, for example, maintaining railroad car reliability at $90 \%$ requires allocating approx. 75,000 US Dollars. The remaining 34 x $2=68$ mathematical models were obtained in the same way for the passenger wagon groups based on the technical characteristics given in Table 1.

Table 2. Optimal quantities for given fleet reliability of $90 \%$ obtained using linear programming

\begin{tabular}{|c|c|c|c|}
\hline $\begin{array}{c}\text { Part } \\
\text { designation }\end{array}$ & Part code & $\begin{array}{c}\text { Unit price in } \\
\text { US Dollars } \\
\left(c_{i=1 . .567}\right)\end{array}$ & $\begin{array}{c}\text { Optimal } \\
\text { quantities } \\
\left(\mathrm{x}_{\mathrm{i}=1.567}\right)\end{array}$ \\
\hline$x_{1}$ & 2218003172 & 10.31 & 0 \\
\hline$x_{2}$ & 2211110230 & 4.32 & 0 \\
\hline$\ldots$. & & & \\
\hline$x_{58}$ & 6216008117 & 32.43 & 1 \\
\hline$x_{59}$ & 2213300466 & 231.4 & 29 \\
\hline$\ldots .$. & & & \\
\hline$x_{224}$ & 6217104501 & 48.83 & 0 \\
\hline$x_{225}$ & 2216160719 & 187.5 & 1 \\
\hline$x_{226}$ & 2213314194 & 49.7 & 3 \\
\hline$\ldots$. & & & \\
\hline$x_{333}$ & 2211001439 & 81.7 & 0 \\
\hline$x_{334}$ & 2214142065 & 450 & 48 \\
\hline$x_{335}$ & 6210042104 & 58.67 & 0 \\
\hline$\ldots .$. & & & \\
\hline$x_{491}$ & 6216103678 & 81.4 & 2 \\
\hline$x_{492}$ & 6214142371 & $4,177.8$ & 1 \\
\hline$\ldots$. & & & \\
\hline$x_{566}$ & 2855573255 & 6.75 & 0 \\
\hline$x_{567}$ & 1111100000 & 0.03 & 0 \\
\hline Calculated goal-function $(Z)=$ & 33,011 US Dollars \\
\hline \multicolumn{2}{|l}{}
\end{tabular}

After obtaining the model for dependency of reliability for the group of wagons in terms of operating time and costs of parts using regression models, phase 2 defined 36 inequalities according to equation (8) and in line with constraints to costs of parts and materials (right side of equation (8) $-b_{1}$ to $b_{36}$ ) as a function of reliability for groups of passenger wagons according to equations (10) and (12) with a given goal function based on equation (7) for calculating optimal costs of maintenance. Shown below in Table 2 is the result of the obtained optimal quantities of parts and materials for some of the total 567 parts and materials which were included in the study, using the linear programming method as well as goal function, while the value of 
optimal costs in the US Dollars necessary for maintaining the reliability of the entire fleet of passenger wagons at the given $90 \%$ level for a total of 36 inequalities.

Table 2 clearly shows that maintaining a level of reliability for the entire fleet of passenger wagons at $90 \%$ for a complete maintenance of passenger wagons requires allocating approx. 33,011 US Dollars. Based on the data from Table 2 . and given the obtained quantities, the cost of a particular required spare part can be calculated, hence the part designated as 2214142065 $\left(334^{\text {th }}\right.$ position) needs an allocation of 450 US Dollars $\times$ 48 items $=21,600$ US Dollars. This problem is solved according algorithm block scheme described in 2.3 .

\section{CONCLUSION}

The aim of this paper is to devise a new model for optimising stocks in the maintenance of passenger wagons which is based on a set level of reliability. The newly devised model serves as a management tool for deciding which policies to choose, i.e., strategies for maintaining passenger wagon fleets, and which are based on reliability. The research was conducted using real data on maintenance processes at a rail carrier with a fleet of 216 passenger wagons over a period of one year. The data on maintenance is classified into 36 groups of technical characteristics. A mathematical model of railroad car reliability in the dependency of operating time as well as models of reliability in the dependency of maintenance costs is obtained for each of the mentioned groups. The newly developed model algorithm provides an estimation of maintenance costs and requirements for spare parts regarding each desired level of reliability, thereby optimising stocks of necessary materials, i.e., costs. The model algorithm also provides an estimation of reliability for the desired value of costs, i.e., stocks of necessary parts, where reliability is attainable based on the respective costs. Also, the derived models and algorithms will enable company management in the future to forecast the requirements of new railroad cars, equipment and devices. Finally, it should be emphasised that the newly devised model is applicable not only for railroad carrier companies, but also for all companies that have processes for maintaining vehicle fleets.

\section{REFERENCES}

[1] Lloyd.C.: Asset management, ICE Publishing, London, 2010.

[2] Knežević, J.: Increasing Profitability and Reliability through Failure Management, Maintworld, Nr.4, 2016.

[3] Tsantiotis, D., et al.: A cost-efficient applicitation of the Reliability-Centered Maintenance method for small-scale usage, 2nd International Conference on Experiments/Process/SystemModelling/ Simulation/Optimization, Athens (Greece), 2007.

[4] Gits, C.,W.: On the maintenance concept for a technical system - a framework for design, Eindhoven University of Technology, 1984.

[5] Epler, I.: Maintenance management models of technical systems, Military Technical Courier (Belgrade, Serbia), Vol.LXI, No.1, 2012.
[6] Kishor, S., Bobbio, A.: Reliability and Availability Engineering, Cambridge University Press, United Kingdom, 2017.

[7] Milković,V., Štefanić, N., Perić, M.: An Analysis of device and equipment failures by means of business intelligence methods, Transactions of FAMENA, Vol. 33, No.4, pp. 53-62, 2009.

[8] Conradie, P. et al.: Quantifying system reliability in rail transport in an ageing fleet environment, The South African Journal of Industrial Engineering, Vol.26, pp.128-142, No.2, 2015.

[9] Szkoda, M., Kaczor,G.: Reliability and availability assessment of diesel locomotive using Fault Tree Analysis, Archives of Transport, Vol. 40, pp. 65-75, 2016.

[10] Milutinović, D. and Lučanin, V.: Relationship between reliability and availability of railway vehicles, FME Transactions (Belgrade, Serbia), Vol. 33, pp.135-139, 2005.

[11] Eisenberger, D., Fink, O.: Assessment of maintenance strategies for railway vehicles using Petrinets, Transportation Research Procedia 27, pp. 205-214, 2017.

[12] Corman, F., Kraijema, S., Godjevac, M., Lodewijks, G.: Optimizing preventive maintenance policy: A data-driven application for a light rail braking system, Journal of Risk and Reliability, Vol. 231(5),pp. 534-545, 2017.

[13]Nikšić, M.: Influence of maintenance quality on the service life of railway vehicles, doctoral thesis, Faculty of Transport and Traffic sciences, Zagreb, 2010. (in Croatian)

[14]Backhaus, K. et al.: Multivariate Analysenmethoden -eine anwendungsorientierte Einfuhrung, Springer Lehrbuch, Berlin, 2005.

[15] Cameron, C. and Windmeijer, F.: An R-squared measure of goodness of fit for some common nonlinear regression models, Journal of Econometrics. Vol. 77 (2), 1997.

[16] Rama,S., Srividya, S.,and Deepa Belatti: A Linear Programming approach for optimal scheduling of workers in a Transport Corporation, International Journal of Engineering Trends and Technology (IJETT) Volume 45 (10), 2017.

[17]Hillier, F.S I Lieberman, G.J.: Introduction to Operations Research, Seventh Edition, McGrawHill, New York, 2001.

[18] Solaja, O., Abiodun, J., Abioro, M.,Ekpudu, J., Olasubulumi, O.; Application of linear programming techniques in production planning, International Journal of Applied Operational Research, Vol.9 No.3, pp. 11-19, 2019.

\section{НОВИ МОДЕЛ ПОУЗДАНОСТИ ОПТИМИЗАЦИЈЕ ЗАЛИХА ЗА ОДРЖАВАЊЕ ЖЕЛЕЗНИЧКИХ ПУТНИЧКИХ ВАГОНА}

\section{В. Милковић, Д. Лисјак, Д. Колар}

Код железничких путничких вагона данас се јавља велики број отказа услед претеране експлоатације, 
тако да је планирање одржавања сложено и скупо. Посебну пажњу треба посветити планирању залиха делова за вагоне. Развијен је модел који коришћењем података добијених из процеса одржавања служи за оптимизацију залиха делова према постављеном нивоу поузданости. Подаци о плану рада и поправке вагона, средње време између отказа и трошкова одржавања прикупљени су у периоду од једне године од стране превозника за целокупан железнички возни парк. У првој фази развоја модела применом методе регресије израђени су математички модели зависности поузданости са аспекта времена коришћења воза и трошкова резервних делова за вагоне сврстане у групе према техничким карактеристикама. У другој фази је решаван проблем оптималних залиха применом линеарних метода програмирања. Нови модел може да се користи у пракси као алат за оптимизацију потребних залиха делова базиран на постављеном нивоу поузданости опреме и утврђеним трошковима одржавања. 